\title{
Kernos
}

Revue internationale et pluridisciplinaire de religion grecque antique

$34 \mid 2021$

Varia

\section{The Sanctuaries of Ancient Kythnos}

\section{Erika Angliker}

\section{OpenEdition \\ Journals}

\section{Electronic version}

URL: https://journals.openedition.org/kernos/3915

DOI: 10.4000/kernos.3915

ISSN: 2034-7871

\section{Publisher}

Centre international d'étude de la religion grecque antique

\section{Printed version}

Date of publication: 31 December 2021

Number of pages: 290-295

ISBN: 978-2-87562-305-8

ISSN: 0776-3824

\section{Electronic reference}

Erika Angliker, "The Sanctuaries of Ancient Kythnos", Kernos [Online], 34 | 2021, Online since 31 December 2021, connection on 15 March 2023. URL: http://journals.openedition.org/kernos/3915; DOI: https://doi.org/10.4000/kernos.3915

This text was automatically generated on 15 March 2023.

All rights reserved 


\title{
The Sanctuaries of Ancient Kythnos
}

\author{
Erika Angliker
}

\section{REFERENCES}

Alexander MAZARAKIS AINIAN, The Sanctuaries of Ancient Kythnos, Rennes, Presses

Universitaires de Rennes, 2019. 1 vol. 21,8 × 27,8 cm, 156 p. (Archéologie \& Culture). ISBN :

978-2-7535-7709-1.

1 The study of religious practices in the Cyclades, particularly during the Iron Age and Archaic period, has traditionally concentrated on Delos. This situation has changed dramatically over the past decade, however, thanks to archaeological discoveries of important sanctuaries unmentioned in the literary sources or inscriptions. ${ }^{1}$ The most important sites for the study of Cyclades in these early periods, at Despotiko, Tenos, and Kythnos, are, again, known chiefly through the material evidence. ${ }^{2}$ The present volume, by the director of the excavations at the homonymous ancient polis on the latter island, summarizes the results of the Kythnos Excavation Project from the initial survey in 1990 and the first excavations in 2002 until recently. Over this period, A. Mazarakis Ainian (A.M.A.) has regularly published articles and papers presenting his findings as well as discussions of the materials and cult practices at the sanctuaries of Kythnos. This volume collects much of this research on the island in a single place for the first time. The aim is, then, not to provide a detailed account of all the archaeological work on the island, but rather to give an overview of its antiquities. While evidence is presented from across the island, the main focus is on the sanctuaries of the ancient polis and, especially, the Archaic sanctuary of the Middle Plateau (probably dedicated to Apollo and Artemis) since its excavation is complete and the materials have been widely studied. The target audience for the book includes scholars but extends to members of the broader public with an interest in archaeology, ancient Greece, ancient religion, and the Aegean islands. As such, it includes a concise synthesis of an enormous amount of research as well as references for further reading, and scholars will welcome the rich illustrations. 
2 The book consists of five chapters. The first presents a historical survey of Kythnos, beginning with a synopsis of the modern scholarship and the main literary and epigraphic sources. This account starts with the mythical foundation of the polis by the Dryopians and touches on its participation in the Persian wars, its connections with Athens in the Classical period, probable period of Macedonian rule in Hellenistic times, the decline of the island in the Roman period, its abandonment in the sixth and seventh centuries, and its resettlement with a new capital on the steep slope of Kastro on the northern coast.

Chapter 2 provides an overview of the ancient sites of Maroulas, the earliest settlement in the Cyclades (8500-6500 BCE), and Skouries, where Early Cycladic structures interpreted as metallurgical kilns for copper smelting have been identified along with circular and rectangular towers dating mainly to the Late Classical period. The fortified acropolis on the north coast, which served as the capital of the island during the Byzantine period, has revealed ceramics from the Bronze Age, Iron Age, and Classical periods as well. The survey then moves through the Early Iron Age site of Myrsini, the fortified acropolis of Kastellas that was abandoned in the Archaic period, the smaller acropolis of Kastraki occupied in the Hellenistic period, a rural sanctuary near the church of Ay. Marina, several suburban cult sites near the ancient town, and various remains of marble architecture found across the island. As A.M.A. notes, further discoveries may yet come to light, for travellers to Kythnos in the 18th and 19th centuries mention remains that have not been identified thus far.

Chapter 3 presents part of the findings from Vryokastro, which is the modern name for the site of the ancient polis. The discussion mentions Vryokastraki, an islet that was connected to the Kythnos in antiquity. The chapter also presents the findings from the main necropolis, located outside the wall that protected the city's south side, and the ancient harbour, from which underwater excavations recovered several items, mainly from the Roman Imperial period. Other structures in the ancient city mentioned here are the fortification wall, the aqueduct, and some sort of public building of the Hellenistic period (Building 5).

5 Chapter 4, the longest in the book, focuses exclusively on the sanctuaries on the north plateau of Vryokastro. The chapter begins with the finds around the summit, which suggest the presence of a sanctuary from the eighth century BCE through the first century CE. Next, a survey of the structures located on the summit of the acropolis in the southeast corner of the city reveals an important sanctuary consisting of four buildings, two of which (Buildings 3 and 4) are at the north end of the acropolis. Though a complete picture of the architectural layout of the sanctuary and its boundaries awaits further excavations and study, based on the architectural forms and objects recovered in the clearing of the structures, A.M.A. offers some preliminary conjectures about their function, plausibly identifying Building 1 as a temple and Building 4 as a cultic edifice. He also argues that the architectural layout of Buildings 3 and 4 and associated findings suggest a cult of Demeter, perhaps as Thesmophoros, noting connections between the goddess's worship at Kythnos and at Eleusis, though he withholds judgement regarding whether the former cult occupied the entire plateau of the acropolis. The shape of the plateau and uneven distribution of the votives, he further suggests, may point to the existence of more than one cult in this area. Whatever artefacts the unexcavated sanctuaries on the acropolis of Vryokastro contain, it is crucial to have these partial results of the few examples in the Cyclades 
identified with the cult of Demeter published so that research on the worship of this goddess in the archipelago can progress. The next part of the chapter presents the evidence from the other sanctuaries on the middle plateau, which were dedicated to Asklepios, Aphrodite, and Samothracian gods. Here, A.M.A. and his team excavated Building 1, dating to the Late Classical period but used mainly during the Hellenistic period, and Building 2, dating to the Hellenistic period. Both buildings seem to have had religious functions, though, at this point, the case is less strong for Building 2. The architectural forms and materials, which include form vases, statuettes, and a colossal statue of Aphrodite, suggest to A.M.A. that Building 1 housed a cult of that goddess and Asklepios. An inscription found in the area with the words "of Samothracian gods" (IG XII 5,1057$)$ provides evidence of the worship of these deities. The last and longest part of the chapter reports on the best-known sanctuary on the Middle Plateau, located on its northern edge, the one probably dedicated to Apollo and Artemis. The detailed discussion of the architecture of the double oikos (A and B), built no later than the seventh century BCE, and of the two altars set perpendicular to the longitudinal axis of the temple pays particular attention to the arrangement of the objects within the adyton of Oikos B, which were found in situ. The votive findings at the sanctuary, remarkable for their variety, richness, and, in certain cases, exoticism, came from the Cyclades as well as from distant parts of the Mediterranean (i.e. Egypt, the Levant, Phrygia, and Italy). According to the A., these votives were either purchased in markets elsewhere in the Aegean (i.e. Crete, Corinth, Athens, or Euboea) or brought to the island by Kythnian navigators who had acquired them on their voyages. Amid the book's highquality illustrations, the detailed photographs of this sanctuary and the associated objects are especially impressive. The chapter closes with a discussion of the identity of the divinities worshipped at this sanctuary. A.M.A. concludes provisionally that the cult was dedicated to Apollo and Artemis based on Hellenistic coins showing Apollo on one side and a kithara on the other-indicating connections with Delos-the votives, and the distinctive architectural layout of the sanctuary.

6 The fifth and last chapter explores the significance of the Archaic religious architecture of Kythnos through an overview of the character the sanctuaries of the polis that places them in the broader context of life on the island. The variety of findings encountered at the sanctuary of Apollo and Artemis is consistent with the importance of the island's main city as a stop on the east-west route across the Aegean. A.M.A. also contrasts the modest schist architecture of the Kythnian sanctuaries with the marble sanctuaries elsewhere in the Cyclades (e.g. Despotiko, Naxos, Paros, and Siphnos), at which a number of kouroi were dedicated. Despite their modest nature, he observes, the Kythnian sanctuaries presented a maritime façade visible from afar. He then refers back to the uniqueness of the adyton in Oikos B, describing it as crucial for understanding the function of this type of structure since, so far, very few objects have been found in situ within an adyton.

7 At a time when the picture of the religious practices in the Cycladic archipelago is evolving rapidly, the present volume provides a useful synopsis of the island's history, a listing of the key bibliographical references, and many images of archaeological sites on Kythnos. Taken together, these features of the book paint a fairly detailed picture of religious life on ancient Kythnos. In addition, the discussion of the ties between the island and Attica/Eleusis, Cyprus, and Delos reveals the close interconnectivity in this part of the Greek world. The Sanctuaries of Ancient Kythnos, therefore, fills a significant 
gap in the scholarship on the Cyclades and, more generally, will be of great interest to those involved in the growing field of insular studies.

\section{NOTES}

1. R. Étienne, "La naissance des dieux dans les Cyclades", in S. AGUSTA-Boularot, S. huber, W. VAN ANDRINGA (eds.), Quand naissent les dieux, fondation des sanctuaires antiques : motivations, agents, lieux, Athens/Rome, 2017, p. 19-32; Fr. DE POLIGNAC, Fr. PROST, "Le laboratoire cycladique", in A. MAZARAKIS AINIAN (ed.), Les sanctuaires archaïques des Cyclades, Rennes, 2017, p. 391-393; Fr. PROST, “Origines du sanctuaire d'Apollon", in R. ÉTIENNE (ed.), Le sanctuaire d'Apollon à Délos, Athens, 2018, p. 155-174.

2. For Despotiko see Y. KouRAYos, Despotiko, A Journey in Time. Antiparos, Antiparos, 2018; Y. KOURAYos et al., "Ritual Dining at the Sanctuary of Apollo on Despotiko: The Evidence from Building $\Delta "$ ", in A. MAZARAKIS AINIAN (ed.), Les sanctuaires archaïques des Cyclades, cit., p. 345-366. For Tenos see R. ÉTIENNE, N. KOUROU, E. SIMANTONI-BOURniA, H $\alpha \rho \chi \alpha i ́ \alpha$ Tívo, Athens, 2013.

\section{AUTHORS}

\section{ERIKA ANGLIKER}

Institute of Classical Studies - London 